\title{
Purification and Characterization of Cytoplasmic Proteins Synthesized in the Developing Forespores of Bacillus subtilis during Sporulation
}

\author{
By KAZUHITO WATABE, * MARIKO TAKESUE, TAMAE YAMASHITA, \\ TOMIO ICHIKAWA $\dagger$ AND MASAOMI KONDO
}

Faculty of Pharmaceutical Sciences, Osaka University, Yamadaoka 1-6, Suita, Osaka 565, Japan

(Received 18 February 1983)

\begin{abstract}
Forespores of Bacillus subtilis 60015 were isolated from sporulating cells at $t_{5}$ and were incubated with an amino acid mixture containing $\left[{ }^{14} \mathrm{C}\right]$ phenylalanine. Three species of ${ }^{14} \mathrm{C}$ labelled cytoplasmic proteins synthesized in the forespores were purified to homogeneity by gel filtration in the presence of detergents and by ion-exchange chromatography. The molecular weights of the purified proteins, called A, B and C, were estimated by SDS-PAGE as 24200, 11500 and 12700 , respectively. Protein B contained remarkably high amounts of tyrosine $(23.8 \%)$ and alanine $(22.8 \%)$, and proteins $\mathrm{A}$ and $\mathrm{C}$ contained relatively high amounts of glutamate + glutamine, glycine, and alanine $(10 \cdot 4$ to $13.3 \%)$. The synthesis of these proteins can provide markers for the control events in the forespore compartment during sporulation.
\end{abstract}

\section{INTRODUCTION}

Nutritional deprivation in the medium accompanying an alteration of metabolic balance causes an initiation of bacterial sporulation (Schaeffer, 1969; Freese, 1976), where a forespore compartment is formed by the asymmetric partition of the stationary phase cell into two compartments following the rapid growth of a folded mother-cell double-membrane septum. The sporulating cell consists of two discrete sections, and the separation of the sporangium into forespore and mother-cell compartments is useful for investigating the major biochemical changes which take place in the developing forespore during sporulation.

Procedures for isolation of intact forespores have been developed in many species of Bacillus (Andreoli et al., 1973; Ellar \& Posgate, 1974; Fujita et al., 1977; Watabe et al., 1980; Nakayama et al., 1980) and some of the biochemical properties closely related to the developing forespores have been investigated (Eaton \& Ellar, 1974; Ellar \& Posgate, 1974; Andreoli et al., 1975, 1978; Ellar et al., 1975; Fujita et al., 1977; Nakayama et al., 1980; Watabe et al., 1980, 1981; Setlow, 1981). We have developed a $\left[{ }^{14} \mathrm{C}\right]$ phenylalanine-incorporation system using isolated forespores of Bacillus subtilis 60015, and found continuous protein synthesis in the young forespore throughout sporulation. About $75 \%$ of the radioactive amino acid incorporated into the forespore at $t_{5}$ was located in the cytoplasmic fraction, and a major protein labelled with $\left[{ }^{14} \mathrm{C}\right]$ phenylalanine was found to have a molecular weight of about 20000 and lower molecular weight polypeptides also contained radioactivity (Watabe et al., 1981). In the present paper, ${ }^{14} \mathrm{C}$-labelled proteins in the forespore cytoplasmic fraction were purified to homogeneity, and their amino acid composition and molecular weights were analysed.

\section{METHODS}

Organism, cultural conditions and media. The transformable Marburg strain of B. subtilis 60015 (metC tryC), originally obtained from Ernst Freese (National Institute of Health, Bethesda, Md., U.S.A.), was used. Bacteria were grown in the nutrient sporulation medium containing nutrient broth, metal mixture, methionine, tryptophan and glucose as described previously (Watabe et al., 1981). The growth stage was identified by $t_{n}$, where $n$ is the number of hours after the end of exponential growth.

$\dagger$ Present address: National Institute of Nutrition, Shinjiku, Tokyo, Japan. 
Preparation of forespores and labelling experiment. Preparation of forespores from sporulating cells at $t_{5}$ and confirmation of their purity were carried out as described previously (Watabe et al., 1981). The labelling experiment with the isolated forespores was performed by incubation with $0 \cdot 1 \mu \mathrm{Ci} \mathrm{L}-\left[\mathrm{U}-{ }^{14} \mathrm{C}\right]$ phenylalanine $\mathrm{ml}^{-1}$ $\left(3.7 \mathrm{kBq} \mathrm{ml} \mathrm{l}^{-1}\right.$ ) and $10 \mu \mathrm{M}$ of each of 20 unlabelled amino acids (Watabe et al., 1981).

Purification of ${ }^{14} \mathrm{C}$-labelled cytoplasmic proteins. (i) Preparation of cell extract. A cell extract of ${ }^{14} \mathrm{C}$-labelled forespores was prepared, as described previously, in the presence of 2 mM-EDTA, 2 mM-phenylmethylsulphonyl fluoride and haemoglobin-Sepharose (Watabe et al., 1981). The haemoglobin-Sepharose was prepared as described by Nakayama et al. (1977).

All column chromatographies were performed at $25^{\circ} \mathrm{C}$. Protein content of the eluate from Sepharose CL-6B was measured by the absorbance at $450 \mathrm{~nm}$ following the addition of $0.8 \mathrm{ml} 4 \%$ (w/v) trichloroacetic acid to $0.2 \mathrm{ml}$ eluate. Protein in eluates from Sephadex G-150 and DEAE Bio-Gel A was estimated from the absorption at $280 \mathrm{~nm}$. Radioactivity was measured as described previously (Watabe et al., 1981).

(ii) Sepharose $C L-6 B$ gel filtration. After dialysing overnight at $25^{\circ} \mathrm{C}$ against $50 \mathrm{~mm}$-carbonate buffer (pH 9.8) containing $8 \mathrm{M}$-urea, $0 \cdot 1 \mathrm{M}-\beta$-mercaptoethanol and $0 \cdot 4 \%$ (w/v) SDS (UMS buffer), the cell extract was applied to a column $(2.0 \mathrm{~cm}$ diam. $\times 90 \mathrm{~cm})$ of Sepharose CL-6B equilibrated with UMS buffer and eluted with the same buffer.

(iii) Sephadex G-150 gel filtration. Gel filtration by Sephadex G-150 was performed using columns of two different lengths; short $(1.5 \mathrm{~cm}$ diam. $\times 100 \mathrm{~cm})$ and long $(1.5 \mathrm{~cm} \mathrm{diam} . \times 150 \mathrm{~cm})$. Both columns were equilibrated and eluted with $50 \mathrm{~mm}$-carbonate buffer ( $\mathrm{pH} 9 \cdot 8$ ) containing $0 \cdot 1 \%(\mathrm{w} / \mathrm{v})$ SDS.

(iv) DEAE Bio-Gel A chromatography. The sample was dialysed overnight against $50 \mathrm{~mm}-\mathrm{Tris} / \mathrm{HCl}$ buffer $(\mathrm{pH} 8.0)$ and was then applied to a column $(0.9 \mathrm{~cm}$ diam. $\times 13 \mathrm{~cm})$ of DEAE Bio-Gel A (Bio-Rad) equilibrated with the same buffer. The column was washed with $20 \mathrm{ml}$ of the same buffer and eluted stepwise with $15 \mathrm{ml}$ portions of the same buffer containing $0.2 \mathrm{M}, 0.4 \mathrm{M}$ and $0.6 \mathrm{M}-\mathrm{NaCl}$, successively.

$S D S-P A G E$. Proteins were fractionated by electrophoresis either in tubes or in a slab apparatus. For tube gel electrophoresis, proteins were treated with detergents and were run in gels containing $7 \cdot 5 \%(\mathrm{w} / \mathrm{v})$ of polyacrylamide at $6 \mathrm{~mA}$ per tube for about $5 \mathrm{~h}$ as described by Fairbanks et al. (1971). The gels were then stained with Coomassie brilliant blue-R and destained. For slab gel electrophoresis, samples were solubilized in Laemmli solubilization buffer (Laemmli, 1970), and were separated with the SDS-PAGE system of Ames (1974). The slab gels, which were $2.0 \mathrm{~mm}$ thick and consisted of $4 \%(\mathrm{w} / \mathrm{v})$ stacking gel and a $15 \%(\mathrm{w} / \mathrm{v})$ separating gel, were run at $28 \mathrm{~mA}$ until the tracking dye flowed out from the bottom (approximately $4 \mathrm{~h}$ ). The gels were stained with Coomassie blue, destained and dried.

The tube gels containing radioactive samples were cut into $1.5 \mathrm{~mm}$ pieces with a gel slicer, and the radioactivity was measured after solubilization of the gels by ammoniacal $\mathrm{H}_{2} \mathrm{O}_{2}$ solution as described previously (Watabe et al., 1981).

Amino acid analysis. The purified proteins were hydrolysed in $6 \mathrm{M}-\mathrm{HCl}$ in evacuated sealed tubes at $110^{\circ} \mathrm{C}$ for $14 \mathrm{~h}$. The solutions were evaporated to dryness in vacuo, redissolved in $0 \cdot 2 \mathrm{M}$-citrate buffer ( $\mathrm{pH} 2 \cdot 2$ ), and analysed on a JEOL amino acid analyser (model JLC-6H).

Chemicals. Tris, EDTA, phenylmethylsulphonyl fluoride and SDS were obtained from Sigma. L-[U${ }^{14} \mathrm{C}$ ]phenylalanine (specific activity $513 \mathrm{mCi} \mathrm{mmol}^{-1} ; 18.9 \mathrm{GBq}$ ) was purchased from Amersham. All other materials were of analytical grade quality.

\section{RESULTS}

\section{Purification of ${ }^{14} \mathrm{C}$-labelled cytoplasmic proteins}

Forespores were isolated from sporulating cells at $t_{5}$ and were incubated with an amino acid mixture containing $\left[{ }^{14} \mathrm{C}\right.$ ]phenylalanine for $4 \mathrm{~h}$. The cell lysate of ${ }^{14} \mathrm{C}$-labelled forespores was fractionated on Sephadex G-200 eluted with $0 \cdot 1 \mathrm{M}-\mathrm{Tris} / \mathrm{HCl}$ buffer $(\mathrm{pH} 8.0)$. Two peaks of radioactive fractions were obtained and the main peak was eluted at a position corresponding to a molecular weight of more than 200000 (data not shown). SDS-PAGE of the ${ }^{14} \mathrm{C}$-labelled cytoplasmic protein resulted in one sharp peak with a molecular weight of about 20000 and broad peaks of about 10000 and 50000 (Watabe et al., 1981). The molecular size of the radioactive proteins implied from the elution pattern of Sephadex G-200 with a non-denaturing buffer was quite different from that estimated by SDS-PAGE, which suggested an aggregation of these proteins. Therefore, the cell lysate was dialysed against $50 \mathrm{mM}$-carbonate buffer (pH 9.8) containing $8 \mathrm{M}$-urea, $0.1 \mathrm{M}-\beta$-mercaptoethanol and $0.4 \%(\mathrm{w} / \mathrm{v})$ SDS to disaggregate the proteins, and was applied to a Sepharose CL-6B column. As expected, more than $85 \%$ of the radioactivity was eluted at fractions 34 to 54 which correspond to molecular weights of less than 50000 (Fig. 1 $a$ ). These fractions were pooled and then applied to the short column of Sephadex 

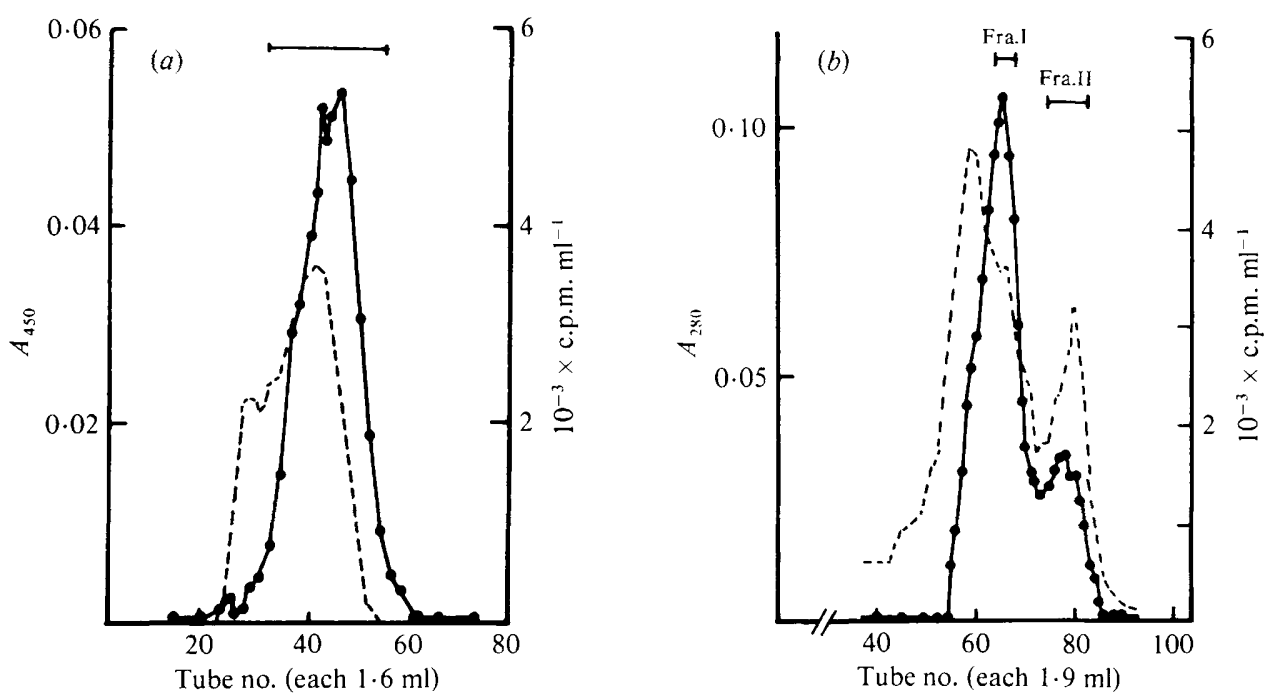

Fig. 1. Gel filtration of ${ }^{1+} \mathrm{C}$-labelled cytoplasmic fraction in isolated forespores of $B$. subtilis 60015 . The cell lysate was applied to a Sepharose CL-6B column (a); radioactive fractions (indicated by the bar) were pooled and then applied to Sephadex G-150 column $(b)$. Protein in the eluates was estimated from the absorbance at $450 \mathrm{~nm}$ or at $280 \mathrm{~nm}$. Protein $(---)$; radioactivity (O).

G-150 in the presence of $0.1 \%(\mathrm{w} / \mathrm{v})$ SDS (Fig. $1 \mathrm{~b}$ ). Radioactivity eluted in a high-molecularweight peak (fractions 53 to 70 ) containing $78.7 \%$ of the applied radioactivity and a lowmolecular-weight peak (fractions 70 to 82 ). The pool of fractions 60 to 68 was called Fra.I and that of 70 to 82 , Fra.II.

Fra.I was re-chromatographed on the long Sephadex G-150 column, and one major peak of protein with radioactivity was obtained. After pooling the main fraction, this gave only a single protein peak on SDS-PAGE analysis, which coincided with the radioactive peak in the tube gel (data not shown); this homogeneous protein was called protein $\mathrm{A}$.

The low-molecular-weight peak of Fra.II was applied to the long Sephadex G-150 column in the presence of $0.1 \%(w / v)$ SDS (Fig. 2). One major radioactive peak, called Fra.III, was obtained by this step, but SDS-PAGE analysis of the main peak fraction of Fra.III yielded at least four protein bands with molecular weights of 11300 to 14000 (data not shown). Further purification of Fra.III was then accomplished by chromatography on DEAE Bio-Gel A; proteins $B$ and $C$ were obtained from this process by stepwise elution with $0.2 \mathrm{M}$ and $0.4 \mathrm{M}-\mathrm{NaCl}$, respectively (Fig. 3). The homogeneity of these proteins was confirmed by SDS-PAGE; when they were run on slab gel, both showed only a single protein band and radioactivity comigrated with each of them (data not shown). Further purification of the non-absorbed fraction obtained from the ion-exchange chromatography was unsuccessful because of the small amount of the fraction.

Overall recoveries of radioactivity from the cell lysate in the proteins $\mathrm{A}, \mathrm{B}$ and $\mathrm{C}$ were calculated as $43.5 \%, 8 \cdot 1 \%$ and $4 \cdot 1 \%$, respectively.

\section{Molecular weight}

The molecular weights of the purified proteins were estimated by coelectrophoresis with standard proteins in SDS-PAGE. The molecular weights of the proteins A, B and C were estimated as 24200,11500 and 12700 , respectively.

\section{Amino acid composition}

Amino acid analysis of an acid hydrolysate of the purified proteins revealed all the common amino acids to be present (tryptophan was not examined; Table 1). Proteins A and C contained 


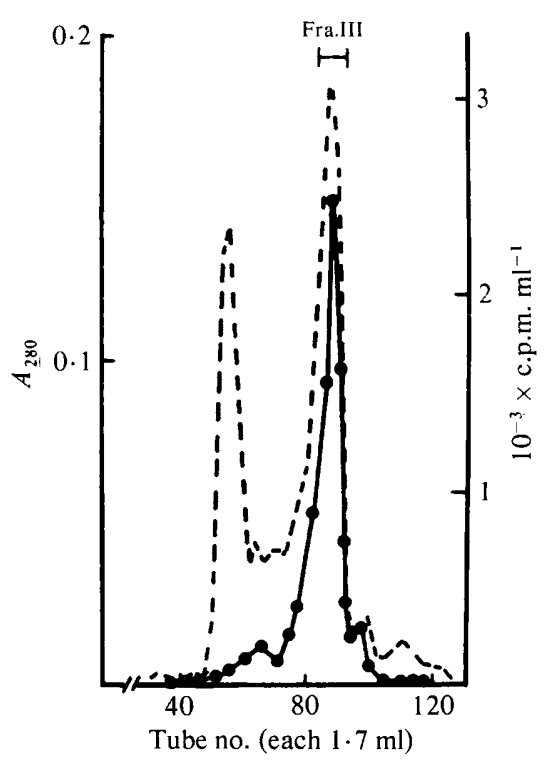

Fig. 2. Gel filtration of Fra.II on Sephadex G-150. ${ }^{14} \mathrm{C}$-labelled protein of Fra.II was rechromatographed on the long column of Sephadex G-150. Protein (--); radioactivity (O).

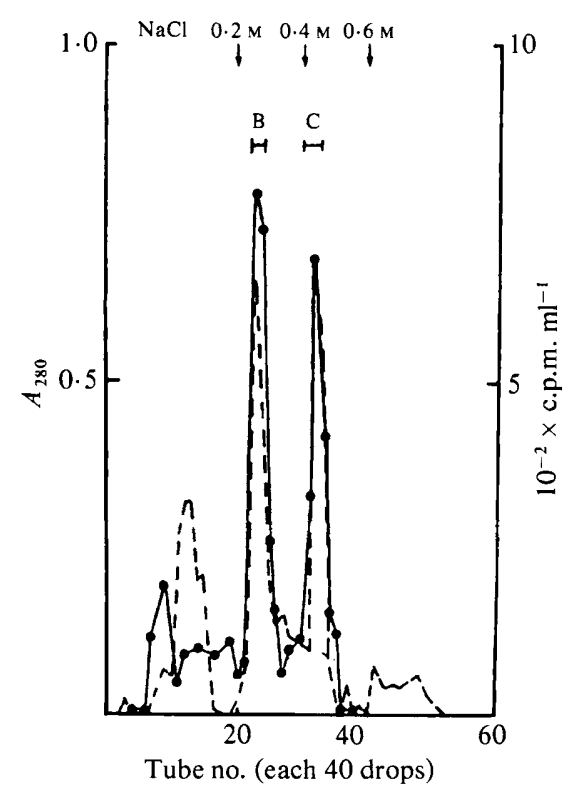

Fig. 3. DEAE Bio-Gel A ion-exchange chromatography of Fra.III. Fra.III, prepared from Sephadex G-150 gel filtration, was applied to a DEAE Bio-Gel A column. The column was equilibrated with $50 \mathrm{~mm}$-Tris/ $\mathrm{HCl}$ buffer ( $\mathrm{pH} 8.0$ ) and eluted stepwise with the same buffer containing 0.2 to $0.6 \mathrm{M}-\mathrm{NaCl}$. Protein (--); radioactivity $(\mathbf{O})$.

a high amount of glutamate + glutamine, glycine, and alanine $(10.4$ to $13.3 \%)$. It is notable that protein B contained a very high amount of tyrosine $(23.8 \%)$ and alanine $(22.8 \%)$, and relatively high amounts of serine and methionine. Each protein contained one unusual peak in the acid hydrolysates, which was expressed as a leucine equivalent. The unknown in protein $\mathrm{A}$ was identified as glucosamine based on its elution time on an amino acid analyser, but those in proteins $\mathbf{B}$ and $\mathbf{C}$ were not identified. 
Table 1. Amino acid composition of proteins $A, B$, and $C$

\begin{tabular}{|c|c|c|c|}
\hline \multirow[b]{2}{*}{ Amino acid } & \multicolumn{3}{|c|}{ Mol $\%$ of protein } \\
\hline & A & B & $\mathrm{C}$ \\
\hline Lys & $4 \cdot 8$ & $1 \cdot 5$ & $4 \cdot 4$ \\
\hline $\mathrm{His}$ & $3 \cdot 2$ & $0 \cdot 8$ & $1 \cdot 2$ \\
\hline Arg & $3 \cdot 6$ & $1 \cdot 3$ & $3 \cdot 8$ \\
\hline Asx ${ }^{*}$ & $9 \cdot 1$ & $3 \cdot 7$ & $8 \cdot 8$ \\
\hline Thr & $4 \cdot 8$ & $1 \cdot 8$ & 4.9 \\
\hline Ser & $7 \cdot 9$ & $13 \cdot 5$ & $8 \cdot 0$ \\
\hline Glx $†$ & $13 \cdot 2$ & $9 \cdot 5$ & $11 \cdot 1$ \\
\hline Pro & $3 \cdot 7$ & $1 \cdot 5$ & $3 \cdot 8$ \\
\hline Gly & $11 \cdot 1$ & $3 \cdot 1$ & $10 \cdot 4$ \\
\hline Ala & $10 \cdot 6$ & $22 \cdot 8$ & $12 \cdot 9$ \\
\hline Cys $\ddagger$ & trace & trace & $0 \cdot 1$ \\
\hline Val & $5 \cdot 7$ & $1 \cdot 8$ & $7 \cdot 7$ \\
\hline Met & $1 \cdot 8$ & $10 \cdot 4$ & $3 \cdot 0$ \\
\hline Ile & $5 \cdot 2$ & $1 \cdot 0$ & $3 \cdot 3$ \\
\hline Leu & $7 \cdot 4$ & 1.9 & $6 \cdot 0$ \\
\hline Tyr & $1 \cdot 9$ & $23 \cdot 8$ & $1 \cdot 2$ \\
\hline Phe & $3 \cdot 6$ & $1 \cdot 0$ & $2 \cdot 6$ \\
\hline Unknown§ & $2 \cdot 4$ & 0.9 & 6.9 \\
\hline $\begin{array}{l}\text { * Aspa } \\
\dagger \text { Gluta } \\
\ddagger \text { Calcu } \\
\S \text { Calcu }\end{array}$ & $\begin{array}{l}\text { cid }+ \\
\text { acid }+ \\
\text { as cys } \\
\text { as leu }\end{array}$ & $\begin{array}{l}\text { argine. } \\
\text { tamine } \\
\text { acid. } \\
\text { equiv }\end{array}$ & \\
\hline
\end{tabular}

\section{DISCUSSION}

The developing forespores of B. subtilis 60015 show changes in the specific activity of several enzymes and in the protein profile of the cytoplasm (Watabe et al., 1980), and also show continuous protein synthesis throughout forespore maturation (Watabe et al., 1981). Among the forespores isolated at $t_{5}, t_{9}$ and $t_{13}$ (corresponding to early stage $\mathrm{V}$, late stage $\mathrm{V}$ and stage $\mathrm{VI}$ of sporulation, respectively), $t_{5}$ forespores showed the highest activity of protein synthesis (Watabe et al., 1981). Low-molecular-weight cytoplasmic proteins (molecular weight of about 20000 and polypeptides of lower molecular weight) were highly labelled with $\left[{ }^{14} \mathrm{C}\right]$ phenylalanine when the isolated forespores at $t_{5}$ were incubated with amino acid mixture, and the polypeptides corresponding to them in their molecular sizes were found in developing forespores after late stage $\mathrm{V}$ and in mature spores, but not in vegetative cells or mother-cell compartments (Watabe et $a l ., 1980,1981)$. The results strongly suggest that these proteins are synthesized in the developing forespores during the middle stages of sporulation. The purification of these proteins was first tried by conventional gel filtration with $\mathrm{Tris} / \mathrm{HCl}$ buffer. The elution pattern of radioactive proteins, however, was quite different from that expected from the electrophoretic profile in SDS gels (Watabe et al., 1981), which suggested an aggregation of the cytoplasmic protein. Changes of molecular size and activity of spore cytoplasmic enzymes have been shown in many species of Bacillus, for example, glucose dehydrogenase in heated spores of $\boldsymbol{B}$. subtilis is present in an inactive form with a molecular weight of about 40000 and treatment of the inactive enzyme with EDTA or dipicolinic acid converts it into an active form with a molecular weight of about 100000 (Hachisuka \& Tochikubo, 1971). Analysis of cytoplasmic proteins in forespores or dormant spores of $B$. subtilis 60015 by PAGE in the absence of SDS often gives an unresolved profile (our preliminary data). These results, therefore, suggest that cytoplasmic proteins in forespores and mature spores tend to aggregate. Thus, purification of the ${ }^{14} \mathrm{C}$-labelled cytoplasmic proteins was carried out in the presence of detergents.

The molecular weights of the purified proteins with radioactivity, called A, B and C, were estimated as 24200,11500 and 12700 , respectively. There is little possibility that these polypeptides are proteolytic products produced by forespore proteases during preparation of the cell lysate because ${ }^{14} \mathrm{C}$-labelled forespores were ruptured in the presence of phenylmethylsul- 
phonyl fluoride, haemoglobin-Sepharose and EDTA, which are specific inhibitors for serine and metal proteases (Nakayama et al., 1977). Some unique low-molecular-weight basic proteins are found in Bacillus megaterium (Setlow \& Primus, 1975; Setlow, 1975a, b; 1978), B. subtilis (Johnson \& Tipper, 1981 ; Tipper et al., 1981), and Bacillus cereus (Yuan et al., 1981), and some of these are closely related immunologically (Yuan et al., 1981). In B. megaterium, seven sporespecific low-molecular-weight proteins are degraded by spore proteases to produce free amino acids, which support much of the protein synthesis early in spore germination (Setlow \& Primus, 1975). These proteins are found in the forespore; consequently they may be synthesized within the forespore (Dignam \& Setlow, 1980), and some of them (Setlow's proteins A and B) are associated with spore DNA in vivo and are involved in the high resistance of spore DNA to UV light (Setlow, 1975a; Setlow \& Setlow, 1979). In the present study, protein B was found to contain a high level of tyrosine and alanine, comprising about half of the total amino acids present (Table 1). When amino acid compositions of the low-molecular-weight proteins from dormant spores of several Bacillus species are compared, it can be seen that proteins B and E of $B$. megaterium and $\gamma$ of $B$. subtilis contain a high amount of glutamate $(25.6 \%, 22 \cdot 2 \%$ and $28 \%$, respectively) (Setlow, 1975b; Setlow, 1978; Johnson \& Tipper, 1981); protein B of B. subtilis 60015 was the only polypeptide which contained a similar amount of tyrosine. Since proteins A, $B$ and $C$ of $B$. subtilis 60015 were purified in the presence of detergents, biological activity of these polypeptides could not be measured, but the high content of tyrosine in protein B suggest that this protein acts as a reserve of that amino acid in the forespore core during sporulation.

As mentioned above, the existence of these polypeptides is presumed to be closely associated with one of the biologically specific events taking place within the forespore at $t_{5}$. Gene expression in the forespore and mother-cell compartments is regulated in a manner different from that suggested for B. megaterium (Eaton \& Ellar, 1974), B. subtilis (Linn \& Losick, 1976) and B. cereus (Andreoli et al., 1978), therefore it is expected that the synthesis of proteins A, B and $\mathrm{C}$ would be a good marker for the study of the control mechanism of gene expression in the forespore compartment during development of sporulation.

We thank Dr Barry P. Rosen for fruitful discussions and critical reading of the manuscript.

\section{REFERENCES}

AMES, G. F.-L. (1974). Resolution of bacterial proteins by polyacrylamide gel electrophoresis on slabs. Journal of Biological Chemistry 249, 634-644.

Andreoli, A. J., Suehiro, S., SakiYama, D., Takemoto, J., Vivanco, E., LaRa, J. C. \& Klute, M. C. (1973). Release and recovery of forespores from Bacillus cereus. Journal of Bacteriology 115, 11591166.

Andreoli, A. J., Saranto, J., Baecker, P. A., Suehiro, S., Escamilla, E. \& Steiner, A. (1975). Biochemical properties of forespores isolated from Bacillus cereus. In Spores VI, pp. 418-433. Edited by G. Gerhardt, R. N. Costilow and H. L. Sadoff. Washington, D. C.: American Society for Microbiology.

Andreoli, A. J., Saranto, J., Caliri, N., Escamilla, E. \& Pina, E. (1978). Comparative study of proteins from forespore and mother-cell compartments of Bacillus cereus. In Spores VII, pp. 260-264. Edited by G. Chambliss and J. C. Vary. Washington, D. C.: American Society for Microbiology.

DignaM, S. S. \& Setlow, P. (1980). In vivo and in vitro synthesis of the spore-specific proteins $A$ and $C$ of Bacillus megaterium. Journal of Biological Chemistry 255, 8417-8423.

Eaton, M. W. \& Ellar, D. J. (1974). Protein synthesis and breakdown in the mother-cell and forespore compartments during spore morphogenesis in Bacillus megaterium. Biochemical Journal 144, 327-337.

Ellar, D. J. \& Posgate, J. A. (1974). Characterization of forespores isolated from Bacillus megaterium at different stages of development into mature spores. In Spore Research 1973, pp. 21-40. Edited by A. N. Barker, G. W. Gould \& J. Wolf. London \& New York: Academic Press.

Ellar, D. J., Eaton, M. W., Hogarth, C., WilkinSon, B. J., Deans, J. \& Nauze, J. L. (1975). Comparative biochemistry and function of forespore and mother-cell compartments during sporulation of Bacillus megaterium cells. In Spores VI, pp. 425-433. Edited by P. Gerhardt, R. N. Costilow \& H. L. Sadoff. Washington, D. C.: American Society for Microbiology.

Fairbanks, G., Steck, T. L. \& Wallach, D. F. H. (1971). Electrophoretic analysis of the major polypeptides of the human erythrocyte membrane. Biochemistry 10, 2606-2617.

FREESE, E. (1976). Metabolic control of sporulation. In Spore Research 1976, pp. 1-32. Edited by N. Barker, G. W. Gould \& J. Wolf, London \& New York: Academic Press.

Fujita, Y., Ramaley, R. \& Freese, E. (1977). Location 
and properties of glucose dehydrogenase in sporulating cells and spores of Bacillus subtilis. Journal of Bacteriology 132, 282-293.

HACHISUKA, Y. \& TochIKUBO, K. (1971). Reactivative action of ethylenediaminetetraacetic acid or dipicolinic acid on inactive glucose dehydrogenase obtained from heated spores of Bacillus subtilis. Journal of Bacteriology 107, 442-447.

Johnson, W. C. \& Tipper, D. J. (1981). Acid-soluble spore proteins of Bacillus subtilis. Journal of Bacteriology 146, 972-982.

LAEMMLI, U. K. (1970). Cleavage of structural proteins during the assembly of the head of bacteriophage T4. Nature, London 227, 680-685.

LINN, T. \& Losick, R. (1976). The program of protein synthesis during sporulation in Bacillus subtilis. Cell 8, 103-114.

Nakayama, T., Munoz, L. \& DoI, R. H. (1977). A procedure to remove protease activities from Bacillus subtilis sporulating cells and their crude extracts. Analytical Biochemistry 78, 165-170.

Nakayama, T., Kurogi, Y., Irikura, M., Matsuo, H. \& SASAKI-WADA, A. (1980). Fractionation and biochemical properties of the mother cell and forespore fractions from sporulating cells of Bacillus subtilis. Journal of Biochemistry 88, 317-326.

SCHAEFFER, P. (1969). Sporulation and the production of antibiotics, exoenzymes, and exotoxins. Bacteriological Review 33, 48-71.

SETLOW, P. (1975a). Identification and localization of the major proteins degraded during germination of Bacillus megaterium spores. Journal of Biological Chemistry 250, 8159-8167.

Setlow, P. (1975b). Purification and properties of some unique low-molecular-weight basic proteins degraded during germination of Bacillus megaterium spores. Journal of Biological Chemistry 250, 81688175 .
SETlow, P. (1978). Purification and characterization of additional low-molecular-weight basic proteins degraded during germination of Bacillus megaterium spores. Journal of Bacteriology 136, 331-340.

SETLOW, P. (1981). Biochemistry of bacterial forespore development and spore germination. In Sporulation and Germination, pp. 13-28. Edited by $\mathrm{H}$. S. Levinson, A. L. Sonenshein \& D. J. Tipper. Washington, D. C.: American Society for Microbiology.

Setlow, P. \& Primus, G. (1975). Protein metabolism during germination of Bacillus megaterium spores. I. Protein synthesis and amino acid metabolism. Journal of Biological Chemistry 250, 623-630.

Setlow, B. \& SETlow, P. (1979). Localization of lowmolecular-weight basic proteins in Bacillus megaterium spores by cross-linking with ultraviolet light. Journal of Bacteriology 139, 486-494.

Tipper, D. J., Johnson, W. C., Chambliss, G. H., Mahler, I., ARnaud, M. \& Halvorson, H. O. (1981). Acid-soluble polypeptides of Bacillus subtilis spores. In Sporulation and Germination, pp. 178-183. Edited by H. S. Levinson, A. L. Sonenshein \& D. J. Tipper. Washington, D. C.: American Society for Microbiology.

WATABE, K., IIDA, S., WADA, R., ICHIKAWA, T, \& KONDO, M. (1980). Characterization of forespores isolated from Bacillus subtilis at each stage of sporulation. Microbiology and Immunology 24, 79-82.

Watabe, K., Iida, S., NaKamura, K., IChiKaWa, T. \& Kondo, M. (1981). Protein synthesis in the isolated forespores from sporulating cells of Bacillus subtilis. Microbiology and Immunology 25, 545-556.

Yuan, K., Johnson, W. C., Tipper, D. J. \& Setlow, P. (1981). Comparison of various properties of lowmolecular-weight proteins from dormant spores of several Bacillus species. Journal of Bacteriology 146, 965-971. 